\title{
Penegakan Hukum Terhadap Pencemaran Limbah Peternakan Sapi Potong
}

\section{Law Enforcement Against Pollution of Beef Cattle Livestock Waste}

\author{
Fauzul Romansah \\ Fauzulromansyah@gmail.com
}

Universitas Islam Negeri Raden Intan Lampung

Submitted: Feb 28, 2020; Reviewed: Mar 23, 2020; Accepted: Apr 27, 2020

Info Artikel
Kata Kunci: Limbah Sapi; Penegakan
Hukum; Polusi.
Keywords: Cow Waste; Law
Enforcement; Pollution.

DOI:

https://doi.org/10.25041/aelr.v1i1.2081
Abstrak

Bisnis sapi potong tidak hanya berdampak positif dalam pemenuhan kebutuhan pangan, terutama pemenuhan gizi dalam bentuk protein hewani. Namun juga berdampak buruk pada lingkungan dan manusia. Dampak lingkungan ini disebabkan oleh faktor perumahan, faktor makanan, dan faktor pencegahan dan pengendalian penyakit. Faktor perumahan berkontribusi terhadap pencemaran lingkungan dalam bentuk polusi udara, dan polusi air. Penelitian ini dilakukan menggunakan pendekatan analisis deskriptif yang menghasilkan kesimpulan jika faktor-faktor yang dapat mempengaruhi pencemaran lingkungan dari usaha penggemukan sapi potong, termasuk faktor sistem manajemen yang manajemennya tidak baik, terutama dalam penyelesaian kotoran hewan dapat menimbulkan aroma tidak sedap, pencemaran air, dan pencemaran tanah. Sedangkan pada faktor makanan sangat berdampak negatif dikarenakan sisa pakan dan perluasan lahan subur untuk produksi sumber makanan sapi melalui

Administrative and Environmental Law Review is a journal published by Faculty of Law, Universitas Lampung, under a Creative Commons Attribution-ShareAlike 4.0 International License. 
deforestasi yang menghasilkan efek gas rumah kaca. Diperlukan pengelolaan kotoran ternak agar lebih ramah terhadap lingkungan, serta memberikan vaksin terhadap ternak untuk mencegah penularan penyakit ternak kepada manusia.

\section{Abstract}

The beef cattle business does not only have a positive impact in meeting food needs, especially the fulfillment of nutrition in the form of animal protein. But it also has a negative impact on the environment and people. This environmental impact is caused by housing factors, food factors, and disease prevention and control factors. The housing factor contributes to environmental pollution in the form of air pollution and water pollution. This research was conducted using a descriptive analysis approach which resulted in the conclusion that the factors that can affect environmental pollution from beef cattle fattening business, including management system factors whose management is not good, especially in the settlement of animal manure can cause unpleasant odors, water pollution, and pollution. soil. Meanwhile, the food factor has a very negative impact due to leftover feed and the expansion of fertile land for the production of food sources for cattle through deforestation which produces greenhouse gas effects. Manure management is needed to make it more environmentally friendly, as well as providing vaccines for livestock to prevent transmission of livestock diseases to humans.

\section{A. Pendahuluan}

Kemajuan ilmu pengetahuan dan teknologi telah membawa masyarakat pada kehidupan yang semakin heterogen. Pun halnya dengan gaya atau pola makannya terutama dalam konsumsi daging sapi dan berbagai olahannya. ${ }^{1}$ Dahulu masyarakat kesulitan mengkonsumsi daging sapi, namun daging sapi saat ini telah banyak dirubah menjadi makanan olahan yang tersedia di pasaran. ${ }^{2}$ Seiring dengan meningkatnya kebutuhan konsumsi daging sapi dalam

\footnotetext{
${ }^{1}$ Mardan Umar, "Internalisasi Nilai Kedamaian Melalui Pendidikan Kedamaian Sebagai Penguatan Pembangunan Karakter Pada Masyarakat Heterogen", Jurnal Waskita, Vol 1 No.1, (2017), hlm 85.

${ }^{2}$ Fatmawati, Rostin, Jamal Nasir Baso, "Faktor-Faktor Yang Mempengaruhi Permintaan Daging Sapi Di Indonesia", Jurnal Ekonomi, Vol 1 No.1, (2016), hlm 130-133.
} 
rangka pemenuhan gizi protein hewani, permintaan pasar menuntut adanya peningkatan produksi daging sapi khususnya sapi jenis sapi potong. Produksi daging sapi dilakukan melalui beberapa tahapan dimulai pada proses pemilihan indukan, proses perkawinan, proses melahirkan, proses penggemukan hingga proses pemotongan. Dari beberapa proses tersebut, penggemukan sapi dinilai paling banyak mempunyai dampak terhadap lingkungan ${ }^{3}$ karena dalam proses penggemukan sapi memakan waktu yang cukup panjang dan perlu memperhatikan faktor-faktor pendukung.

Faktor-faktor yang perlu diperhatikan dalam usaha penggemukan diantaranya faktor perkandangan, faktor pemberian pakan, faktor pencegahan serta penanggulangan penyakit. Ketiga faktor tersebut masing-masing memberikan dampak negatif terhadap lingkungan apabila sistem manajemen pengolahannya tidak dilakukan dengan baik. ${ }^{4}$

Dalam pengelolaan limbah kotoran ternak hingga saat ini belum terciptanya teknologi yang mumpuni serta mudah untuk diterapkan secara global, baik oleh peternak rumahan maupun perusahaan peternakan sapi potong guna menghindari pencemaran lingkungan beserta dampaknya bagi manusia. Teknologi pengolahan limbah ternak ini sangat dibutuhkan mengingat dampak negatif yang ditimbulkan oleh usaha penggemukan sapi ini bertentangan dengan dua prinsip dasar politik hukum lingkungan ${ }^{5}$ yang tercantum dalam Pasal $28 \mathrm{H}$ ayat (1) dan Pasal 33 ayat (4) Undang-Undang Dasar Negara Republik Indonesia Tahun 1945 yakni dimasukkannya prinsip perlindungan Hak Asasi Manusia (HAM) atas lingkungan hidup ${ }^{6}$, yakni manusia memiliki hak untuk mendapatkan lingkungan hidup yang nyaman, aman, dan menunjang kesehatan. Seperti yang kita ketahui bahwa dampak negatif dari limbah kotoran usaha penggemukan sapi ini dapat menganggu aktivitas dan lingkungan hidup masyarakat, bahkan dapat mEnularkan penyakit bagi manusia serta penegasan prinsip keberlanjutan dan berwawasan lingkungan dalam penyelenggaraan perekonomian nasional, ${ }^{7}$ penelitian ini membahas mengenai bagaimanakah penegakan hukum lingkungkan terhadap pencemaran lingkungan limbah kotoran sapi berdasarkan Undang-Undang Nomor 32 tahun 2009 tentang Perlindungan dan Pengelolaan Lingkungan Hidup pasal 60 jo Pasal 104 serta apakah yang menjadi faktor pencemaran limbah peternakan sapi potong.

Sedangkan tujuan dari penelitian ini untuk mengetahui penegakan hukum terhadap pemcemaran lingkungan yang berasal dari limbah peternakan sapi serta dampak negatif dari limbah kotoran ternak yang seringkali memberi dampak buruk bagi lingkungan. Bahkan acapkali pemberian pakan ternak tidak memperhatikan ketersediaan tumbuhan di lingkungan hidup, maka dibutuhkan sistem pengolahan manajemen yang baik untuk meminimalisir dampak negatif yang ditimbulkan oleh usaha penggemukan sapi potong terhadap lingkungan hidup. Penelitian ini mengambil tema tentang penegakan hukum terhadap pencemaran limbah peternakan sapi potong, maka dalam hal ini yang menjadi objek pembahasan adalah limbah yang berasal dari usaha penggemukan sapi potong yang memberikan dampak nagatif terhadap lingkungan.

\footnotetext{
${ }^{3}$ Reza Steflyando, Abubakar, Alex Saleh, “Analisis Kelayakan Usaha Sapi Potong Dengan Metode Zero Waste Farming Di Kecamatan Parompong”, Reka Integra, Jurnal Online Teknik Industri, Vol 1 No. 4, (2013), hlm 229.

${ }^{4}$ Suyitman, Surjono Hadi Sutjahjo, Catur Herison, Muladno, "Status Keberlanjutan Wilayah Berbasis Peternakan Di Kabupaten Situbondo Untuk Pengembangan Kawasan Agro Politan”, Jurnal Agro Ekonomi, Vol 27 No. 2, (2009), hlm 167.

${ }^{5}$ Dani Amran Hakim, Politik Hukum Lingkungan Hidup Di Indonesai Berdasarkan Undang-Undang Nomor 32 Tahun 2009 tentang Perlindungan dan Pengelolaan Lingkungan Hidup", Fiat Justicia Jurnal Imu Hukum, Vol 9 No.2, (2015), hlm 122124.

${ }^{6}$ Rosmidah Hasibuan, "Pengaturan Hak Atas Lingkungan Hidup Terhadap Kesehatan”, Jurnal Ilmiah Advokasi, Vol 6 No.2, (2018), hlm 98-99.

${ }^{7}$ Muhammad Akib, Politik Hukum Lingkungan, Jakarta, Raja Grafindo Persada, 2012, Hlm 75.
} 


\section{B. Pembahasan}

\section{Penegakan Hukum Terhadap Pencemaran Lingkungan Limbah Ternak Sapi}

Pemeliharaan ternak selalu menimbulkan dampak terhadap lingkungan, tidak terkecuali terhadap usaha penggemukan sapi potong. ${ }^{8}$ Seperti pada usaha penggemukan sapi potong yang dilakukan oleh Pt. Juang Jaya Abadi Alam, usaha ini berlokasi di Jalan Lintas Sumatera Kilo Meter 40 Bakauheni, Desa Kota Dalam Kecamatan Sidomulyo Kabupaten Lampung Selatan. Usaha ini menitikberatkan pada kegiatan penggemukan sapi potong secara intensif disamping usaha-usaha lain seperti Program Pemberdayaan dan Kemitraan Pembibitan Sapi Potong. ${ }^{9}$ Usaha penggemukan sapi potong ini juga harus memperhatikan prinsip-prinsip hukum lingkungan seperti yang sudah diatur dalam undang- undang. Terdapat dua prinsip dasar hukum lingkungan berdasarkan UUD 1945 setelah perubahan sebagaimana yang tercantum di dalam Pasal 28 ayat (1) dan pasal 33 ayat (4) UUD 1945. Dua prinsip dasar tersebut meliputi prinsip perlindungan Hak Asasi Manusia (HAM) atas lingkungan hidup serta penegasan prinsip keberlanjutan dan berwawasan lingkungan dalam penyelenggaraan perekonomian nasional. ${ }^{10}$ Dapat dikatakan bahwa perlindungan hak asasi manusia merupakan masalah yang penting dan menjadi materi pokok dalam konstitusi negara hukum modern, ${ }^{11}$ karena pada prinsipnya manusia pasti memerlukan perlindungan terhadap hak-haknya sebagai manusia dan hak-hak tersebut adalah hak yang diakui secara universal sebagai hak-hak yang melekat sebagai hakikat dan kodrat kelahiran manusia.

Salah satu materi HAM yang termaktub di Pasal 28H Undang-Undang Dasar 1945 yang berbunyi: "setiap orang berhak hidup sejahtera lahir dan batin, bertempat tinggal, dan mendapatkan lingkungan hidup yang baik dan sehat serta berhak memperoleh pelyanan kesehatan"12 sehingga jelaslah bahwa perlindungan dan pengelolaan lingkungan hidup harus memiliki tujuan untuk menjamin pemenuhan dan perlindungan hak atas lingkungan hidup yang sehat dan sejahtera sebagai bagian dari hak asasi manusia. ${ }^{13}$ Sedangkan yang dimaksud dengan prinsip berkelanjutan dan berwawasan lingkungan seperti yang dijelaskan dalam Pasal 33 ayat (4) UUD 1945 bahwa "perekonomian nasional diselenggarakan berdasarkan atas demokrasi ekonomi dengan prinsip berkelanjutan, berwawasan lingkungan" yang menyiratkan bahwa dalam menyelenggarakan perekonomian baik itu usaha atau sebagainya tidak mengakibatkan keruskan lingkungan. ${ }^{14}$ Dapat kita lihat bahwa dalam usaha penggemukan sapi potong ini haruslah senantiasa menjaga dan meningkatkan tata lingkungan hidup, memperhatikan hak khalayak ramai, serta harus menjamin keseimbangan alam untuk kelanjutan dan kemajuan masa depan. Karena pada dasarnya bahwa kegitan ekonomi pasti tidak dapat dilepaskan dari aspek lingkungan hidup, karena dalam sejarahnya kebijakan lingkungan memang muncul sebagai reaksi terhadap kegiatan ekonomi yang tidak berwawasan lingkungan. ${ }^{15}$

\footnotetext{
${ }^{8}$ Irham Widyono, Sarmin, "Pemberdayaan Peternak Marginal : Studi Kasus Di Wilayah Banguntapan Bantul, "Indonesian Journal of Community Engagement", Vol 2 No.2, (2017), hlm 164.

${ }^{9}$ Yanuar Muas, Tinjauan Hukum Islam Tentang Jual Beli Kotoran Sapi Sebagai Pupuk Kandang (Studi pada PT. Juang Jaya Abdi Alam) dalam http://repository.radenintan.ac.id /1277/4/BAB_III.pdf diakses tanggal 10 Mei 2018

${ }^{10}$ Opcit, hlm 75

11 A. Muhammad Asrun, "Hak Asasi Manusia Dalam Kerangka Cita Negara Hukum”, Jurnal Cita Hukum, Vol 4 No.1, (2016), hlm 137-142.

12 Pasal hasil Perubahan kedua UUD 1945, Bab XA tentang Hak Asasi Manusia, terdiri dari 10 pasal yaitu pasal 28A-Pasal 28J

${ }^{13}$ Ashabul Kahpi, “Jaminan Konstitusional Terhadap Hak Atas Lingkungan Hidup Di Indonesia”, Jurnal Al-Daulah, Vol 2 No.2, (2013), hlm 148-149.

${ }^{14}$ Felisthella Earlene, Jessylyn Evelina Tandrajaya, "Sengketa Penguasaan Tanah Antara Warga Kapuk Poglar RT 07/RW04 Jakarta Barat Dengan Polda Metro Jaya Dintinjau Dari Persepektif Hak Asasi Manusia”, Jurnal Cepalo, Vol 3 No. 2, (2019), hlm 56.

${ }^{15}$ Muhammad Akib, Politik Hukum Lingkungan, Jakarta, Raja Grafindo Persada, 2012, Hlm 91.
} 
Jumlah populasi sapi pada usaha ini tahun 2016 sebanyak \pm 11.000 ekor sapi. Dengan daya tampung kandang pusat penangkaran (breeding center) sebanyak \pm 23.000 ekor, yang dibagi menjadi 12 kandang dan 9 tempat pemberian makan $(\text { feedlot })^{16}$. Dalam sehari 1 ekor sapi menghasilkan limbah berupa kotoran sapi sebanyak $5 \mathrm{~kg}$ per hari, sehingga dari usaha tersebut dihasilkan $55.000 \mathrm{~kg}$ kotoran sapi per hari. Kotoran sapi ini kemudian dimanfaatkan lagi dengan mengolahnya menjadi pupuk kandang. Untuk dapat menjadi pupuk kandang, kotoran sapi ini terlebih dahulu diolah dengan cara dikumpulkan dan diendapkan selama waktu tertentu dengan tujuan untuk mengurangi kandungan gas pada kotoran sapi. Kotoran sapi yang baru dikeluarkan mengandung gas ammonium, hydrogen sulfida, $\mathrm{CO}_{2}$ dan $\mathrm{CH}_{4}{ }^{17}$ yang tinggi. Gas methan ini menghasilkan bau tidak sedap dan mengganggu kesehatan pada manusia, sedangkan polusi pada tanah limbah ini mengakibatkan penurunan daya dukung tanah.

Limbah lainnya yang dihasilkan dari proses perkandangan yakni limbah cair dari kegiatan pembersihan kandang, dan pemandian sapi yang bercampur dengan urine sapi, jika dalam hal ini limbah tersebut langsung dibuang melalui saluran air atau selokan kemudian masuk ke dalam lingkungan tanpa terlebih dahulu melalui proses pengolahan, maka pencemaran air dan tanah tidak dapat terhindarkan. ${ }^{18}$ Pembuangan limbah cair bagi usaha peternakan sapi diatur dalam Peraturan Menteri Lingkungan Hidup Nomor 11 tahun 2009 tentang Limbah Cair yang mengatur kadar bahan kimia terlarut dalam baku mutu air limbah. Limbah cair yang tidak diolah terlebih dahulu sering ditemukan bakteri Salmonella sp, Coxiella Burnetii dan Laptospirosis $^{19}$ yang dapat menimbulkan berbagai penyakit baik secara langsung pada manusia maupun secara tidak langsung yakni melalui hewan perantara yakni anjing, kucing, burung dan tikus.

Pencemaran lingkungan limbah ternak sapi sebenarnya telah diatur dalam undang-undang lingkungan hidup terkait penegakan hukum dampak pencemaran lingkungan yang terjadi. ${ }^{20}$ Penegakan hukum tersebut telah diatur dalam Pasal 60 jo Pasal 104 UUPPLH yaitu Pasal 60: "setiap orang dilarang melakukan Dumping limbah dan atau bahan kemedia lingkungan hidup tanpa izin". Pasal 104: " setiap orang yang melakukan dumping limbah dan atau bahan ke media lingkungan hidup tanpa izin sebagaimana dimaksud dalam pasal 60, dipidana dengan pidana penjara paling lama tiga tahun dan denda paling banyak tiga miliar rupiah". Eksternalitas dalam bentuk negatif dari usaha penggemukan sapi potong juga timbul akibat manajemen pemberian pakan yang kurang baik, hal ini terjadi mulai dari cara pengangkutan bahan pakan hingga pengolahan sisa pakan. Pengangkutan bahan pakan sapi khususnya bahan tambahan pakan sapi yang terbuat dari moleses (tetes tebu) diusahakan agar tidak tercecer di tanah dalam waktu yang lama dan dalam jumlah yang banyak, demikian pula terhadap sisa pakan molesses yang tidak habis dimakan sapi. ${ }^{21}$ Molasses yang berada di permukaan tanah

\footnotetext{
${ }^{16} \mathrm{Ibid}$, hlm 74

${ }^{17}$ Fianda Revina Widyastuti, Upaya Pengelolaam Lingkungan Usaha Peternakan Sapi di kawasan Usaha tani Terpadu Bangka Botanical Garden Pangkal Pinang dalam http://eprints.undip. ac.id/40627/ - (2013) diakses tanggan 10 Mei 2018

18 Sarwani, Nardi Sunardi, E. Nurzaman AM, Masno Marjohan, Hamsinah, "Penerapan Ilmu Manajemen Dalam Pengembangan Agroindustri Biogas Dari Limbah Kotoran Sapi Yang Berdampak Pada Kesejahteraan Masyarakat Desa Sindalaya Kec. Tanjung Siang Kab. Subang”, Jurnal Abadi Masyarakat Humanis, Vol 1 No. 2, (2020), hlm 77.

19 Khairiyah, Zoonosis dan Upaya Pencegahannya (Kasus Sumatera Utara), dalam https://media.neliti.com/media/publications/123958-ID-zoonosis-dan-upaya-pencegahannya-kasus-s.pdf diakses tanggal 10 mei 2018

${ }^{20}$ Rosmidah Hasibuan, "Analisis Dampak Limbah/Sampah Rumah Tangga Terhadap Pencemaran Lingkungan Hidup”, Jurnal Ilmiah Advokasi, Vol 4 No.1, (2016), hlm 47-48.

${ }^{21}$ Ludfia Windyasmara, Ambar Pertiwiningrum, Lies Mira Yusiati, "Pengaurh Jenis Kotoran Ternak Sebagai SUBSTRAAT Dengan Penambahan Serasah Daun Jati (Tectora Grandis), Terhadap Karakteristik Biogas Pada Proses Fermentasi, Jurnal Buletin Peternakan, Vol 36 No. 1, (2012), hlm 40-41.
} 
dapat mempengaruhi struktur tanah yang mengakibatkan degradasi kesuburan tanah yang mengakibatkan penurunan kesuburan tanah ${ }^{22}$.

\section{Faktor Penyebab Terjadinya Pencemaran Lingkungan Limbah Ternak Sapi}

Faktor pencegahan serta penanggulangan penyakit merupakan salah satu faktor penting yang perlu diperhatikan dalam usaha penggemukan sapi potong karena penyakit merupakan salah satu faktor penghambat dalam usaha ini. ${ }^{23}$ Penyakit yang menyerang pada sapi berdampak pula terhadap manusia maka apabila penanggulangannya tidak dilakukan dengan baik maka dampaknya akan meluas baik terhadap manusia, hewan ternak itu sendiri dan terhadap lingkungan. Umumnya penyakit pada sapi disebabkan oleh bakteri Coxiella Burnetii dan Laptospirosis. Bakteri tersebut menyerang sapi hingga mengakibatkan sapi menjadi sakit. Jika penanggulangan penyakit ini tidak dilakukan dengan baik maka berdampak pula terhadap kotoran dan urine yang dikeluarkan dari hewan tersebut, dan pengelolaan kotoran yang tidak baik dapat menimbulkan penyakit. Bakteri Salmonella sp, juga sering dijumpai pada kotoran sapi, bakteri ini juga dapat menjangkiti manusia yang melakukan kontak baik langsung maupun tidak langsung dengan kotoran sapi ini. Penyakit-penyakit yang ditimbulkan oleh bakteri-bakteri tersebut antara lain demam, diare, kehilangan nafsu makan, gangguan pernafasan, gangguan reproduksi, miningitis dan pneumonia ${ }^{24}$.

Faktor-faktor yang mengakibatkan efek negatif tersebut perlu mendapat perhatian yang serius dalam upaya pencegahan dan penanggulangannya terhadap lingkungan. Mengingat usaha penggemukan sapi dalam jumlah besar dapat memproduksi kotoran berupa fasses dan urine sapi dengan jumlah besar pula, tidak dapat menghindarkan diri dari bau menyengat dan tidak enak sehingga mengganggu pernafasan bagi masyarakat yang tinggal di sekelilingnya. ${ }^{25}$ Maka diperlukan pengaturan mengenai tata ruang kelola usaha ${ }^{26}$ penggemukan sapi dalam area khusus yang diperuntukkan bagi usaha tersebut dan sejenisnya. Selain itu perlu adanya teknologi peralatan pengolah kotoran sapi yang dapat menghindarkan dampak negatif dari kotoran sapi sebelum diolah menjadi pupuk kandang. Teknologi ini dapat membantu pengelola agar tidak bergantung dengan alam. Pada proses pentirisan dan pengendapan kotoran sapi basah dapat menggunakan mesin pengering tanpa bergantung dengan panas terik mata hari. Sehingga bau menyengat dari kotoran sapi pada saat musim penghujan dapat terhindarkan. Pengolahan limbah cair dari faktor perkandangan perlu dimanajemen dengan baik, limbah dari urine sapi, air bekas pembersihan kandang dan air bekas pemandian sapi perlu dikelola dahulu sebelum dibuang ke lingkungan. Air limbah usaha pengemukan sapi ini dibuang setelah dikelola sehingga kandungan airnya memenuhi standar baku mutu air limbah usaha peternakan sebagaimana yang dianjurkan dalam Peraturan Menteri Lingkungan Hidup Nomor 11 tahun 2009 tentang Baku Mutu Air Limbah bagi usaha/kegiatan peternakan sapi dan babi. Pengelolaan limbah cair yang baik tidak memberikan dampak negatif terhadap lingkungan bahkan dapat memberikan dampak positif bagi usaha pertanian. ${ }^{27}$

Teknologi dalam rangka pemberian pakan dan pengolahan sisa paka juga perlu diperhatikan. Pemberian pakan khususnya pakan buatan hendaknya diberikan dan

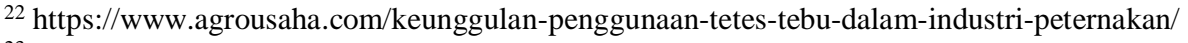

${ }^{23}$ Ahmad Basuki, "Pertanggungjawaban Pidana Pejabat Atas Tindakan Mal Administrasi Dalam Penataan Izin Di Bidang Lingkungan, “Jurnal Perspektif, Vol 16 No. 4, (2011), hlm 252.

${ }^{24}$ Ibid, hlm. 119

${ }^{25}$ Nurul Listiyani, Muzahid Akbar Hayat, Subianta Mnadala, "Penormaan Pengawasan Izin Lingkungan Dalam Pencegahan Pencemaran Dan Kerusakan Lingkungan Hidup Dalam Eksploitasi Sumber Daya Alam”, Jurnal Media Hukum, Vol 25 No. 2, (2018), hlm 218.

${ }^{26}$ Muhar Junef, "Penegakan Hukum Dalam Rangka Penataan Ruang Guna Mewujudkan Pembangunan Berkelanjutan", Jurnal Penelitian Hukum De Jure, Vol 17 No. 4, (2017), hlm 377.

${ }^{27}$ Nommy HT Siahaan, Hukum limgkungan dan ekologi pembangunan, Bandung, Erlangga 2004, hlm 10
} 
diaplikasikan secara tepat sehingga tidak terjadi kerusakan tanah akibat pakan yang tercecer maupun yang diendapkan di atas permukaan tanah dari sisa pakan yang tidak termakan. Mengingat proses penggemukan sapi yang tidak dapat dengan hanya mengandalkan sumber pakan alami dan membutuhkan sumber pakan tambahan buatan, maka dalam proses pengaplikasiannya diperlukan prinsip kehati-hatian, pakan tidak boleh diberikan sembarangan dan perlakuan terhadap pengangkutan dan pengelolaan sisa pakan pun tidak boleh sembarangan.

\section{Penutup}

I. Kesimpulan

Berdasarkan uraian di atas maka, dapat ditarik beberapa kesimpulan diantaranya dalam menjalankan usaha penggemukan sapi baik masyarakat ataupun pelaku usaha harus menjamin dua prinsip dasar dari politik hukum lingkungan yang tercantum dalam Undang-Undang 1945 Pasal 28H ayat (1) dan Pasal 33 ayat (4). Penulis memberikan saran jika pelaku usaha lebih memahami ketentuan perundang-undangan yang mengatur mengenai pengelolaa lingkungan hidup, agar terciptanya prinsip lingkungan hidup yang berwawasan dan berkelanjutan demi kelangsungan hidup di masa depan serta menjaga stablitas masyarakat dalam menghormati hak-hak asasi manusia serta pelaku usaha peternakan dapat memperbaiki ssstem manajemen dalam pengolahan perkandangan, faktor pemberian pakan, faktor pencegahan dan penanggulangan penyakit yang lebih efektif guna mencegah serta meminimalisir dampak negatif yang ditimbulkan dari peternakan sapi potong terhadap lingkungan.

\section{Daftar Pustaka}

A. Buku

Akib, Muhammad, 2012, Politik Hukum Lingkungan, Jakarta, Raja Grafindo Persada.

Siahaan, Nommy HT, 2004, Hukum limgkungan dan ekologi pembangunan, Bandung, Erlangga.

B. Jurnal

Ahmad Basuki, "Pertanggungjawaban Pidana Pejabat Atas Tindakan Mal Administrasi Dalam Penataan Izin Di Bidang Lingkungan, "Jurnal Perspektif, Vol 16 No. 4, 2011. DOI: http://dx.doi.org/10.30742/perspektif.v16i4.88.

Ashabul Kahpi, "Jaminan Konstitusional Terhadap Hak Atas Lingkungan Hidup Di Indonesia”, Jurnal Al-Daulah, Vol 2 No.2, 2013. DOI: https://doi.org/10.24252/ad.v2i2.1472

Dani Amran Hakim, Politik Hukum Lingkungan Hidup Di Indonesai Berdasarkan UndangUndang Nomor 32 Tahun 2009 tentang Perlindungan dan Pengelolaan Lingkungan Hidup", Fiat Justisia Jurnal Imu Hukum, Vol 9 No.2, 2015.DOI: https://doi.org/10.25041/fiatjustisia.v9no2.592

Fatmawati, Rostin, Jamal Nasir Baso, "Faktor-Faktor Yang Mempengaruhi Permintaan Daging Sapi Di Indonesia", Jurnal Ekonomi, Vol 1 No.1, 2016.

Felisthella Earlene, Jessylyn Evelina Tandrajaya, "Sengketa Penguasaan Tanah Antara Warga Kapuk Poglar RT 07/RW04 Jakarta Barat Dengan Polda Metro Jaya Dintinjau Dari Persepektif Hak Asasi Manusia", Jurnal Cepalo, Vol 3 No. 2, 2019. DOI: https://doi.org/10.25041/cepalo.v3no2.1844

Irham Widyono, Sarmin, "Pemberdayaan Peternak Marginal: Studi Kasus Di Wilayah Banguntapan Bantul, "Indonesian Journal of Community Engagement", Vol 2 No.2, 2017. DOI: https://doi.org/10.22146/jpkm.27031

Ludfia Windyasmara, Ambar Pertiwiningrum, Lies Mira Yusiati, "Pengaurh Jenis Kotoran Ternak Sebagai SUBSTRAAT Dengan Penambahan Serasah Daun Jati (Tectora Grandis), Terhadap Karakteristik Biogas Pada Proses Fermentasi, Jurnal Buletin Peternakan, Vol 36 No. 1, 2012. DOI: https://doi.org/10.21059/buletinpeternak.v36i1.1275. 
Mardan Umar, "Internalisasi Nilai Kedamaian Melalui Pendidikan Kedamaian Sebagai Penguatan Pembangunan Karakter Pada Masyarakat Heterogen", Jurnal Waskita, Vol 1 No. 1, 2017. DOI: https://doi.org/10.21776/ub.waskita.2017.001.01.5

Muhammad Asrun, "Hak Asasi Manusia Dalam Kerangka Cita Negara Hukum", Jurnal Cita Hukum, Vol 4 No.1, 2016. DOI: 10.15408/jch.v4i1.3200.

Muhar Junef, "Penegakan Hukum Dalam Rangka Penataan Ruang Guna Mewujudkan Pembangunan Berkelanjutan", Jurnal Penelitian Hukum De Jure, Vol 17 No. 4, 2017. DOI: http://dx.doi.org/10.30641/dejure.2017.V17.373-390.

Nurul Listiyani, Muzahid Akbar Hayat, Subianta Mnadala, "Penormaan Pengawasan Izin Lingkungan Dalam Pencegahan Pencemaran Dan Kerusakan Lingkungan Hidup Dalam Eksploitasi Sumber Daya Alam", Jurnal Media Hukum, Vol 25 No. 2, 2018. DOI: 10.18196/jmh.2018.0116.217-227.

Reza Steflyando, Abubakar, Alex Saleh, "Analisis Kelayakan Usaha Sapi Potong Dengan Metode Zero Waste Farming Di Kecamatan Parompong", Reka Integra, Jurnal Online Teknik Industri, Vol 1 No. 4, 2013.

Rosmidah Hasibuan, "Analisis Dampak Limbah/Sampah Rumah Tangga Terhadap Pencemaran Lingkungan Hidup", Jurnal Ilmiah Advokasi, Vol 4 No.1, 2016. DOI: https://doi.org/10.36987/jiad.v4i1.354.

Rosmidah Hasibuan, "Pengaturan Hak Atas Lingkungan Hidup Terhadap Kesehatan", Jurnal Ilmiah Advokasi, Vol 6 No. 2, 2018. DOI: https://doi.org/10.36987/jiad.v6i2.252.

Sarwani, Nardi Sunardi, E. Nurzaman AM, Masno Marjohan, Hamsinah, "Penerapan Ilmu Manajemen Dalam Pengembangan Agroindustri Biogas Dari Limbah Kotoran Sapi Yang Berdampak Pada Kesejahteraan Masyarakat Desa Sindalaya Kec. Tanjung Siang Kab. Subang", Jurnal Abadi Masyarakat Humanis, Vol 1 No. 2, 2020. DOI: http://dx.doi.org/10.32493/\%25JAMH.v1i2.4792.

Suyitman, Surjono Hadi Sutjahjo, Catur Herison, Muladno, "Status Keberlanjutan Wilayah Berbasis Peternakan Di Kabupaten Situbondo Untuk Pengembangan Kawasan Agro Politan”, Jurnal Agro Ekonomi, Vol 27 No. 2, 2009.

C. Undang-undang

Pasal 28H Ayat (1) dan Pasal 33 Ayat (4) Perubahan Kedua Undang-Undang Dasar 1945. 